\title{
Studies on Hexokinase
}

\section{AN ACTIVATOR OF HEXOKINASE IN ERYTHROCYTES}

\author{
By H. WEIL-MALHERBE AND A. D. BONE \\ Research Department, Runwell Hospital, Wickford, Essex
}

(Received 13 November 1950)

The observation that cytolysates of washed human erythrocytes strongly enhanced the hexokinase activity of rat-brain extracts was made in the course of experiments undertaken to investigate the effects of constituents of human blood on hexokinase. The erythrocyte effect has briefly been mentioned in preliminary reports (Weil-Malherbe, 1948, 1949, 1950).

\section{METHODS}

Preparation of erythrocyte lysates. Blood containing 0.3\% $\mathrm{NaF}$ as anticoagulant was centrifuged, and the packed corpuscles were washed three times with $0.9 \%(v / v)$ aqueous $\mathrm{NaCl}$. Water was added up to the original blood volume and cytolysis was completed by freezing. The solution will henceforth be referred to as haemolysate. Unless otherwise stated, haemolysates were prepared from human blood. in the following sections. Haemolysate, when present, was added in amounts of $1 \mathrm{ml} . / 3 \mathrm{ml}$. of final volume.

Hexokinase activity was usually measured by the rate of disappearance of glucose, and activation effects have been expressed in relation to the activity in the control experiment, designated by 100 .

In manometric experiments containing haemolysate retention of $\mathrm{CO}_{2}$ was determined and an appropriate correction applied.

\section{RESULTS}

\section{Distribution and specificity of the activator}

Frequency distribution. Fig. 1 shows the frequency distribution of the effects obtained with over 300 different human blood samples. The peak of the curve corresponds to a doubling of the activity of the control, while the highest effect observed was a sixfold increase in activity. On the other hand, the effect was frequently absent and some

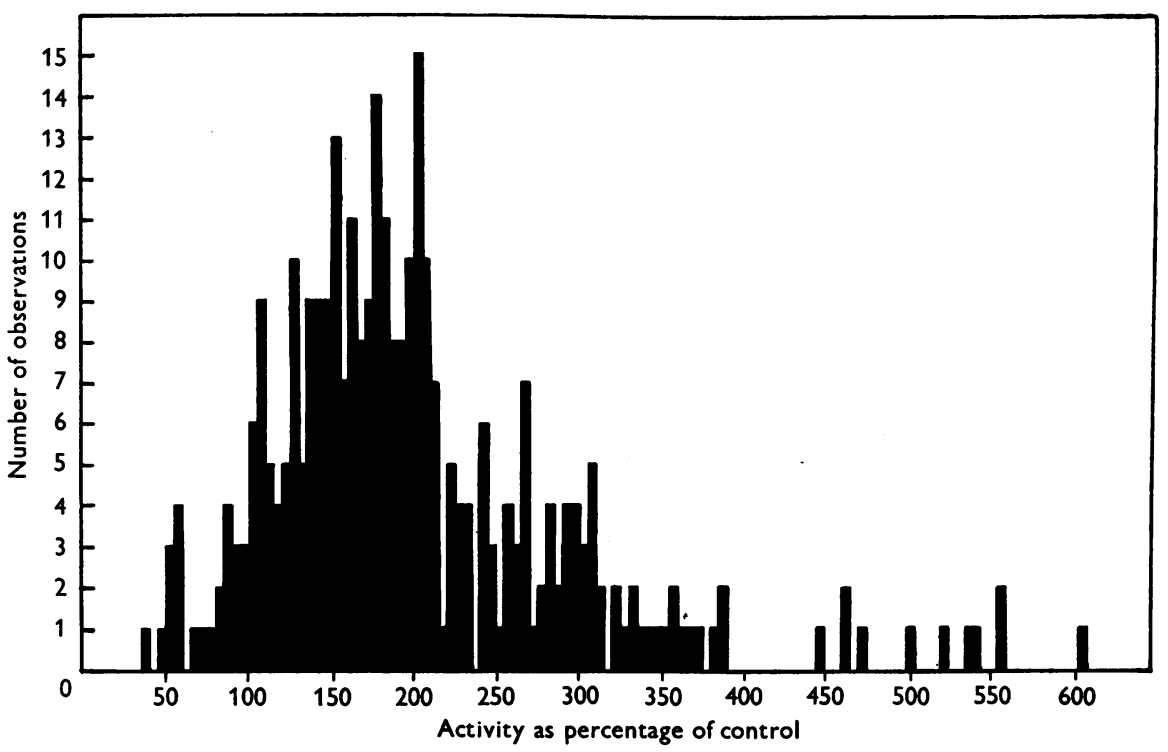

Fig. 1. Frequency distribution of the activation effect of human haemolysates on brain hexokinase.

Measurement of hexokinase activity. The experimental arrangements, analytical methods and preparations used were described in the preceding paper (Weil-Malherbe \& Bone, $1951 a$ ). The standard test solution contained brain extract, glucose, adenosinetriphosphate (ATP) and mineral constituents in the concentrations stated, and only deviations from the standard conditions are expressly mentioned samples even caused inhibition. It has been found in experiments, which will be described elsewhere, that fresh human plasma may have a marked effect on hexokinase activity, depending, amongst other factors, on a concurrent assimilation of carbohydrate. It is assumed that these effects are of hormonal origin. Erythrocyte lysates prepared from blood samples from the same subject, withdrawn in the fasting 
state and at various intervals after administration of glucose, often show changes in their effect on hexokinase, which are parallel to the effects of plasma. But while the variations of hexokinase activity due to the addition of plasma are centred around the level of the control experiment, those due to haemolysates are centred around a higher level of activity. It seems as if the variability of the effects observed with fresh haemolysates were due, at least in part, to these supposedly hormonal effects which are superimposed on the effect of an activator of hexokinase present in red cells. This paper is concerned with the effects and properties of the activator only.

Effect of concentration. On increasing the concentration of the haemolysate the activation effect at first increases steeply, but finally appears to approach saturation (Fig. 2).

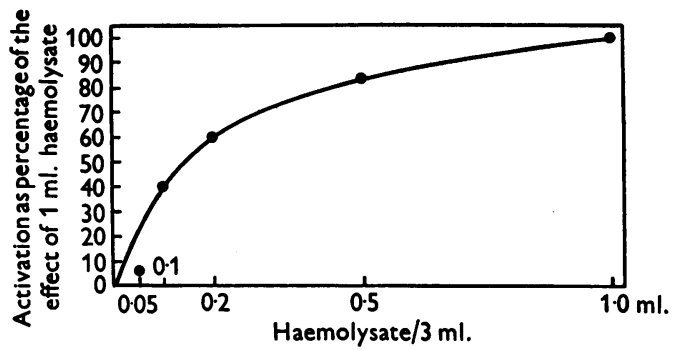

Fig. 2. Effect of haemolysate concentration on the activity of rat-brain hexokinase.

Species differences. Three species other than man, i.e. horse, rabbit and rat, were investigated. Two specimens of horse blood had high activity, but the effect seemed to be less marked and less constant with haemolysates from rat and rabbit (Table 1).
Table 1. Effect of haemolysates from different animals on the activity of rat-brain hexokinase

Hexokinase activity (activity of control $=100$ )

Horse, 1
Horse, 2
Rabbit, 1
Rabbit, 2
Rat, 1
Rat, 2
246 350 118 162 180 115

Activation of muscle and yeast hexokinases. The activation effect is not confined to brain hexokinase, but may also be demonstrated with muscle extract and with a purified yeast hexokinase (Table 2). The response of these enzyme preparations is, however, smaller than that observed with brain extract.

Activation of fructose phosphorylation. Addition of haemolysate to rat-brain extract activates not only the phosphorylation of glucose, but also that of fructose (Table 3). On the other hand, the activity of phosphohexokinase is probably not changed, as will be shown later.

\section{Properties of the activator}

Effect of dialysis. Thorough dialysis of haemolysates was carried out in cellophan sacs against frequently changed distilled water at $0^{\circ}$ until the volume remained constant. Compared with an undialysed portion of the same sample, similarly diluted, the activity was practically unchanged. A similar result was obtained after exhaustive electrodialysis (Table 4). Conversely, ultrafiltrates prepared with the aid of collodion sacs, and concentrated diffusates were inactive. Untreated ultrafiltrates and diffusates were even inhibitory, but they could be freed from inhibitory material (Fe ions?)

Table 2. Effect of haemolysate on the activity of muscle and yeast hexokinases

(Muscle extract: cooled rat muscle ground in Latapie mill, stirred with 1.5 vol. $0 \cdot 033 \mathrm{M}-\mathrm{NaHCO}_{3}$ for 15 min. at $0^{\circ}$. Centrifuged. Supernatant diluted with equal volume of glass-distilled water. Yeast hexokinase solution: 0·1 mg. protein/ml.)

$\begin{array}{lcccc}\text { Enzyme } & \begin{array}{c}\text { Amount } \\ \text { taken } \\ (\text { ml. }\end{array} & \begin{array}{c}\text { Without } \\ \text { haemolysate }\end{array} & \begin{array}{c}\text { With } \\ \text { haemolysate }\end{array} & \begin{array}{c}\text { Activity* } \\ \text { (control=100) }\end{array} \\ \text { Brain } & 0.2 & 0.400 & 0.815 & 177 \\ \text { Muscle } & 0.8 & 0.265 & 0.440 & 136 \\ \text { Yeast } & 0.2 & 0.480 & 0.714 & 132 \\ \text { Haemolysate } & 1.0 & 0.060 & - & -\end{array}$.

* Corrected for the hexokinase activity of the haemolysate.

Table 3. Effect of haemolysate on the phosphorylation of fructose by rat-brain extract

(Fructose: $5.55 \mu \mathrm{mol} . / 3 \mathrm{ml}$. Other constituents in standard concentration.)

\begin{tabular}{|c|c|c|c|c|}
\hline & \multicolumn{2}{|c|}{$\begin{array}{c}\text { Decrease in fructose } \\
\text { (mg.) }\end{array}$} & \multicolumn{2}{|c|}{$\begin{array}{c}\text { Activation } * \\
\text { (activity of control }=100 \text { ) }\end{array}$} \\
\hline & Exp. $1 \dagger$ & Exp. $2 \ddagger$ & Exp. 1 & Exp. 2 \\
\hline $\begin{array}{l}\text { Brain } \\
\text { Haemolysate }\end{array}$ & $\begin{array}{l}0 \cdot 270 \\
0 \cdot 040 \\
0.400\end{array}$ & $\begin{array}{l}0 \cdot 200 \\
0 \cdot 010 \\
0.358\end{array}$ & $\frac{-}{129}$ & $\overline{-}$ \\
\hline
\end{tabular}

* Corrected for activity of haemolysate.

$\dagger$ Fructose estimation by method of Roe (1934).

$\ddagger$ Fructose estimation by method of Nelson (1944). 
by passage through a column of $\mathrm{Na}^{+}$-saturated resin (ZeoKarb 215). The small loss of activity sometimes observed after prolonged dialysis was unaffected by returning the concentrated diffusate (Table 4).

\section{Table 4. Activating effect of dialysed and undialysed haemolysates}

(Undialysed sample diluted to match the haemoglobin concentration of the dialysed sample.)

$\begin{array}{ccc}\begin{array}{c}\text { Haemolysate } \\ \text { specimen } \\ \text { no. }\end{array} & \begin{array}{c}\text { Wexokinase activity of brain extract } \\ \text { (activity of control = 100) }\end{array} \\ 1 & 332 & \begin{array}{c}\text { With dialysed } \\ \text { haemolysate } \\ \text { haemolysate }\end{array} \\ 2 & 144 & 266 \\ 3 & 350 & 146 \\ 4 & 163 & 333^{*} \\ 5 & 233 & 162^{*} \\ & & 212 \\ & & \text { (Same +concen- } \\ \text { trated dialysate) }\end{array}$

Activity of stroma and haemoglobin. The activation effect was not associated either with human corpuscle stroma or with crystalline oxyhaemoglobin of man, horse or rat (Table 5). Some samples of crystalline haemoglobin produced activation, but since the effect was much smaller than that of the complete haemolysate it may be attributed to incomplete removal of the activating factor.

Corpuscle stroma was prepared by repeated washings of the centrifuged residue of a human haemolysate $(500 \mathrm{ml}$.) with 0.033 M-sodium citrate buffer (pH 5.5) (Bernstein, Jones, Erickson, Williams, Avrin \& Macy, 1937). The pinkish residue was finally homogenized in $0.05 \mathrm{M}-\mathrm{NaHCO}_{3}$ (30 ml.). the fraction precipitated between 0.3 and 0.5 saturation. These experiments are therefore not being reported in detail.

Some of the $\left(\mathrm{NH}_{4}\right)_{2} \mathrm{SO}_{4}$ fractions were spectroscopically free of haemoglobin, although they contained the activating factor. This confirms the non-identity of the activating factor and haemoglobin.

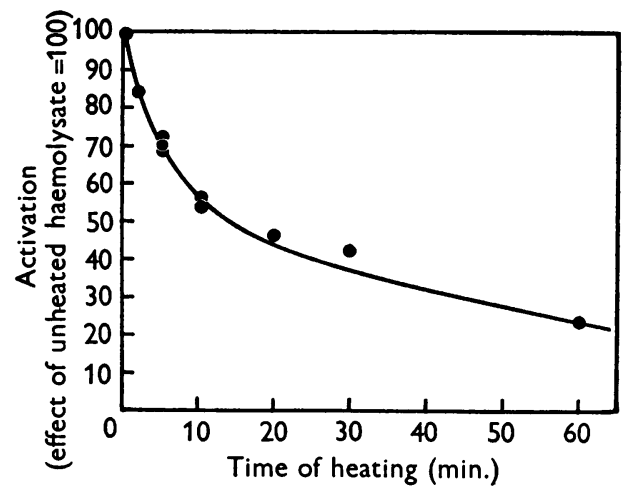

Fig. 3. Heat stability of the activating factor of haemolysates. Samples were heated in a water bath at $100^{\circ}$, cooled and homogenized.

Heat stability. The activating factor of the haemolysate is comparatively stable to heat. In Fig. 3 the time of heating at $100^{\circ}$ is plotted against the activating effect expressed as a percentage of the effect caused by the unheated haemolysate. After $5 \mathrm{~min} .80 \%$, and even after $60 \mathrm{~min} .20 \%$ of the original effect was still preserved. Though these results were repeatedly obtained, it occasionally happened, for unexplained reasons, that the activating effect was more markedly diminished or even completely lost after heating at $100^{\circ}$ for 5 min.

Table 5. Effect of crystalline haemoglobin and of erythrocyte stroma on hexokinase activity of rat-brain extracts

Human oxyhaemoglobin, 1

Human oxyhaemoglobin, 2

Horse oxyhaemoglobin, 1

Horse oxyhaemoglobin, 2 (recrystallized)

Rat oxyhaemoglobin

Human washed stroma

$\begin{array}{cc}\begin{array}{c}\text { Hexokinase activity of brain extract } \\ \text { (activity of control = 100) }\end{array} \\ \begin{array}{c}\text { Plus solution of } \\ \text { crystalline } \\ \text { haemoglobin }\end{array} & \begin{array}{c}\text { Plus complete } \\ \text { haemolysate of same } \\ \text { haemoglobin } \\ \text { concentration }\end{array} \\ 107 & 145 \\ 120 & 155 \\ 152 & 246 \\ 176 & 350 \\ 129 & 174^{*} \\ 94 & 145\end{array}$

* Supernatant, after removal of haemoglobin crystals.
Crystalline human oxyhaemoglobin was prepared according to Drabkin (1949) and horse oxyhaemoglobin according to Taylor \& Hastings (1939). The crystals were dissolved in $0.05 \mathrm{~m}-\mathrm{NaHCO}_{8}$ at $37^{\circ}$ and the solution diluted to match the concentration of the complete haemolysate.

Other fractionation experiments. Attempts to purify the activating factor by isoelectric precipitation or $\left(\mathrm{NH}_{4}\right)_{2} \mathrm{SO}_{4}$ fractionation were disappointing as the activity was spread out over a number of fractions with only a slight peak, which in the case of $\left(\mathrm{NH}_{4}\right)_{2} \mathrm{SO}_{4}$ fractionation appeared in
Even after heating, the activating factor was closely associated with protein. When a fresh haemolysate was heated and separated into supernatant and coagulum (which was well washed and homogenized in the original volume of distilled water) the activity of the two fractions was about the same and was equal to that of the whole of the heated haemolysate (Table 6). The supernatant used in this experiment was turbid and gave a precipitate with trichloroacetic acid. Clear supernatants containing only traces of protein were obtained when the haemolysate was dialysed, 
Table 6. Activating effect of fractions of heated haemolysate on hexokinase activity of rat-brain extract

(Samples were heated in water bath at $80^{\circ}$ for 10 min.)

Activity in presence of fraction

(activity of control $=100$ )

Haemolysate, unheated

287

Heated haemolysate, homogenized

224

Heated haemolysate, supernatant

218

Heated haemolysate, washed coagulum

228

Dialysed haemolysate, unheated

Dialysed haemolysate, heated, supernatant 113

Dialysed haemolysate, heated, washed coagulum 187

Diffusate, concentrated

105

Table 7. Activating effect and hexokinase activity of haemolysates

\begin{tabular}{lccc} 
& \multicolumn{2}{c}{ Decrease in glucose (mg.) } \\
\cline { 2 - 4 } Brain extract & Exp. 1 & Exp. 2 & Exp. 3 \\
Haemolysate & 0.480 & 0.235 & 0.485 \\
Brain extract + haemolysate & 0.070 & 0.040 & 0.100 \\
Brain extract & 0.892 & 0.625 & 0.835 \\
Haemolysate, dialysed & $0 \cdot 650$ & - & - \\
Brain extract + dialysed haemolysate & 0.010 & - & - \\
Brain extract & 1.000 & - & - \\
Haemolysate & 0.320 & 0.560 & - \\
Haemolysate, heated (5 min. at $\left.60^{\circ}\right)$ & 0.060 & 0.075 & - \\
Brain extract +haemolysate & 0 & 0 & - \\
Brain extract + heated haemolysate & 0.590 & 0.780 & -
\end{tabular}

either before or after being heated. Such a supernatant had no activating effect (Table 6). Various other attempts to split off or extract the activating factor from denatured protein were unsuccessful: there was no activity in a concentrated diffusate from heated haemolysate (Table 6), in a trichloroacetic acid extract of red cells or in extracts prepared by heating haemolysates in $\mathrm{NaCl}$ solutions of varying strength $(1-10 \% w / v)$, followed by filtration and dialysis of the filtrate.

\section{The mechanism of the activating effect}

The facts described strongly suggest that the activator of haemolysates is either itself a protein or else a factor which cannot be separated from proteins even after their denaturation. Its heat stability is limited and is therefore not inconsistent with its protein nature. But before a new principle is assumed the question must be examined if the effects can be attributed to any of the known catalysts of glycolysis or associated reactions. The following experiments show that the effect of even the unheated haemolysate cannot be adequately explained by the activity of several such enzymes present.

Hexokinase activity of haemolysates. The hexokinase activity of haemolysates prepared in the manner described was low and could in no way account for the activation of brain hexokinase (Table 7). Moreover, haemolysates could be deprived of hexokinase activity by heating at $60^{\circ}$ for 5 min. or simply by ageing. The decrease of activity after thorough dialysis (Table 7) is probably an effect of ageing. The activating properties of the haemolysate were not affected by these procedures.

It has been tacitly assumed so far that the hexokinase of brain extracts is activated by a factor present in the haemolysate. The reverse possibility, i.e. activation of erythrocyte hexokinase by a factor present in brain extract, was investigated by adding brain 'Kochsaft' and brain extract, heated at $60^{\circ}$ for $5 \mathrm{~min}$., to haemolysate. These additions, however, did not increase the hexokinase activity of haemolysates.

Phosphohexokinase activity of haemolysates. In contrast to their slight hexokinase activity haemolysates contain a very active phosphohexokinase which retains part of its activity after heating for $10 \mathrm{~min}$. at $60^{\circ}$. The addition of haemolysate to brain extract results in an increase of phosphohexokinase activity which is, however, fully accounted for by the activities of the separate components (Table 8). The effect of the activating factor of haemolysates on brain phosphohexokinase can better be studied after heating the haemolysate for $5 \mathrm{~min}$. at $80^{\circ}$, a treatment which completely inactivates phosphohexokinase. The experiment represented by Fig. 4 shows that, while the hexokinase activity of the brain extract was markedly activated by the heated haemolysate, there was no such effect on phosphohexokinase activity. This suggests that the activating factor specifically acts on hexokinase and that the effect cannot be attributed to a more rapid removal of hexosemonophosphates and to a relief of the inhibition caused by them (WeilMalherbe \& Bone, $1951 \mathrm{a}$ ). In fact, a sample of haemolysate which had been heated to inactivate phosphohexokinase had no significaut effect on the inhibition of hexokinase by hexosemonophosphate, although the uninhibited part of hexokinase was activated to about the same extent (Table 9). In any case, it has already been shown (Weil-Malherbe \& Bone, $1951 a$ ) that the brain extracts used quantitatively convert glucose to hexosediphosphate and that there is no evidence that hexosemonophosphate accumulates to such an extent that inhibitory concentrations are reached. Even if it is assumed that inhibitory concentrations of hexosemono. 
Table 8. Phosphohexokinase activity of brain extract, of haemolysate and of both together

(Manometric experiment. Hexosemonophosphate, $20 \mu \mathrm{mol}$.; ATP, $20 \mu \mathrm{mol} . / 3 \mathrm{ml}$.)

$\begin{array}{lc} & \begin{array}{c}\mathrm{CO}_{2} \text { evolution } \\ \text { in } 15 \text { min. } \\ (\mu 1 .)\end{array} \\ \text { Brain extract } & 151 \\ \text { Haemolysate } & 188 \\ \text { Haemolysate, heated at } 60^{\circ} \text { for } 10 \mathrm{~min} . & 144 \\ \text { Brain extract +haemolysate } & 268 \\ \text { Brain extract +heated haemolysate } & 260\end{array}$

$\left(60^{\circ}, 10\right.$ min. $)$

phosphates do accumulate, the effect could only be manifested some time after the start of the reaction. The full activating effect of the haemolysate is, however, displayed immediately.

Triosephosphate dehydrogenase activity of haemolysates. Triosephosphate dehydrogenase activity leads to resynthesis of ATP. This might be an important factor if the concentration of ATP were limiting.

Untreated fresh haemolysates possess considerable triosephosphate dehydrogenase activity, as shown by the disappearance of added hexosediphosphate. The activity disappears after dialysis or in presence of iodoacetate (Table 10). The activating effect is, however, not influenced

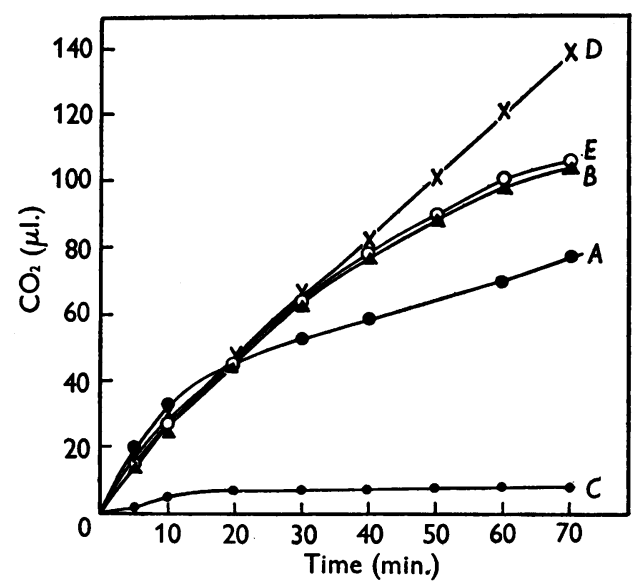

Fig. 4. Activating effect of heated haemolysate on brain hexokinase and phosphohexokinase. Brain extract, 0.1 ml.; ATP, $20 \mu \mathrm{mol}$.; glucose or hexosemonophosphate (HMP), $5 \cdot 55 \mu \mathrm{mol} . / 3 \mathrm{ml}$. Haemolysate heated at $80^{\circ}$ for 5 min. Curve $A$, brain extract, glucose. Curve $B$, brain extract, HMP. Curve $C$, haemolysate, glucose; hremolysate, HMP. Curve $D$, brain extract + haemolysate, glucose. Curve $E$, brain extract + haemolysate, HMP.

Table 9. Effect of heated haemolysate ( 5 min. at $80^{\circ}$ ) on the inhibition of brain hexokinase by hexosemonophosphate

$\begin{array}{ccc}\begin{array}{c}\text { Fructose-6- } \\ \text { phosphate } \\ \begin{array}{c}\text { concentration } \\ (\mathbf{m m})\end{array}\end{array} & \begin{array}{c}\text { Decrease in } \\ \text { glucose } \\ (\mathbf{m g} .)\end{array} & \begin{array}{c}\text { Inhibition } \\ (\%)\end{array} \\ 0 & 0.298 & - \\ 0.55 & 0.185 & \mathbf{3 8} \\ 1.11 & 0.092 & 69 \\ 1.85 & 0.044 & 85\end{array}$

by either treatment (Tables 4 and 11), showing that it is unconnected with triosephosphate dehydrogenase activity.

\section{Table 10. Disappearance of hexosediphosphate in haemolysate}

(Hexosediphosphate, $10 \mu \mathrm{mol} . / 3 \mathrm{ml}$. Haemolysate, mineral constituents and ATP in standard concentration. Duration of experiment, $30 \mathrm{~min}$.)

$\begin{array}{lc}\text { Haemolysate } & \Delta \text { iodoacetate }(1 \mathrm{mM}) \\ \text { Haemolysate + dialysed } & -2 \cdot 33 \\ \text { Haemolysate, do.50 } & \pm 0\end{array}$

\begin{tabular}{|c|c|c|}
\hline \multicolumn{3}{|c|}{ Brain extract + haemolysate } \\
\hline $\begin{array}{l}\text { Decrease in } \\
\text { glucose } \\
\text { (mg.) }\end{array}$ & $\begin{array}{c}\text { Inhibition } \\
(\%)\end{array}$ & $\begin{array}{c}\text { Activating } \\
\text { effect } \\
\text { (control = 100) }\end{array}$ \\
\hline 0.545 & - & 183 \\
\hline $0 \cdot 282$ & 48 & - \\
\hline $0 \cdot 208$ & 62 & - \\
\hline $0 \cdot 180$ & 67 & - \\
\hline
\end{tabular}

Myokinase. It has been shown (Weil-Malherbe \& Bone, $1951 a$ ) that the brain extracts used in these experiments have considerable myokinase activity, since the second phosphate group of ATP as well as added adenosinediphosphate (ADP) are utilized in the reaction. The myokinase activity of the haemolysate, on the other hand, appeared to be low (Table 12). If the activation effect were due to the myokinase activity of the haemolysate one would expect the utilization of ADP to equal that of ATP. Yet, although the reaction is activated by the haemolysate, whether ADP or ATP is used as phosphate donor, the difference in the utilization of the two compounds persists (Table 13). Table 14 shows, furthermore, that a fourfold increase of ATP concentration neither

\section{Table 11. Effect of iodoacetate on rat-brain hexokinase in presence and in absence of haemolysate}

\begin{tabular}{|c|c|c|c|c|c|}
\hline & & $\begin{array}{r}\text { (ac } \\
\text { in pre }\end{array}$ & $\begin{array}{l}\text { nase } \\
\text { f co } \\
f \text { iod }\end{array}$ & $\begin{array}{l}00) \\
(\mathrm{mm}\end{array}$ & \\
\hline & 0 & 0.33 & $1 \cdot 0$ & $\mathbf{3 \cdot 3}$ & 10 \\
\hline $\begin{array}{l}\text { Brain extract } \\
\text { Brain extract }+ \text { haemolysate }\end{array}$ & $\begin{array}{l}100 \\
269\end{array}$ & $\begin{array}{r}93 \\
269\end{array}$ & $\begin{array}{r}82 \\
269\end{array}$ & $\begin{array}{r}77 \\
272\end{array}$ & $\begin{array}{r}62 \\
250\end{array}$ \\
\hline
\end{tabular}


Table 12. Activities of myokinase and adenylic deaminase in haemolysate

(ADP, $10 \mu \mathrm{mol}$; adenylic acid, $20 \mu \mathrm{mol}$; adenylic deaminase (fraction 3P, Weil-Malherbe \& Bone, $1951 b$ ), $1 \mathrm{mg} . / 3 \mathrm{ml}$. Mineral constituents in standard concentration. Duration of experiment, $20 \mathrm{~min}$.)

Ammonia formation ( $\mu \mathrm{mol}$.

Fraction $3 P$

Haemolysate

Haemolysate + fraction $3 P$

$\begin{array}{cc}\begin{array}{c}\text { From } \\ \text { adenylic acid }\end{array} & \begin{array}{c}\text { From } \\ \text { ADP }\end{array} \\ 17 \cdot 7 & 0 \cdot 4 \\ 10 \cdot 6 & \overline{3 \cdot 2}\end{array}$

leads to an increase of the reaction rate of brain hexokinase nor to a diminution of the activating effect of the haemolysate; ATP concentration was therefore not limiting even at the lower level, and under these conditions myokinase cannot be expected to affect the reaction rate. As will be shown in the following paper (Weil-Malherbe \& Bone, $1951 b$ ), the addition of purified myokinase to brain extract does not cause any activation of hexokinase.

Since, in spite of the activation caused by the haemo. lysate, the relative rate of ATP and ADP utilization is hardly changed, it may be assumed that the mechanism of activation is the same in both cases. The fact that ADP utilization is capable of activation at all lends support to the suggestion (Weil-Malherbe \& Bone, $1951 a$ ) that the lowering of the reaction rate if $\mathrm{ATP}$ is replaced by ADP is not due to a

Table 13. Utilization of $A T P$ and $A D P$ by brain hexokinase in presence of haemolysate

(ATP, $10 \mu \mathrm{mol}$.; ADP, $20 \mu \mathrm{mol} . / 3 \mathrm{ml}$. Activity of brain hexokinase with ATP =100.)

\begin{tabular}{|c|c|c|c|c|}
\hline & \multicolumn{4}{|c|}{ Hexokinase activity } \\
\hline & \multicolumn{2}{|c|}{ With ATP } & \multicolumn{2}{|c|}{ With ADP } \\
\hline & Exp. 1 & Exp. 2 & Exp. 1 & Exp. 2 \\
\hline $\begin{array}{l}\text { Brain extract } \\
\text { Brain extract + haemolysate }\end{array}$ & $\begin{array}{l}100 \\
216\end{array}$ & $\begin{array}{l}100 \\
362\end{array}$ & $\begin{array}{r}71 \\
118\end{array}$ & $\begin{array}{r}75 \\
274\end{array}$ \\
\hline
\end{tabular}

Table 14. Activating effect of haemolysate in presence of excess $A T P$

\begin{tabular}{|c|c|c|c|}
\hline \multirow[b]{2}{*}{$\begin{array}{l}\text { ATP added } \\
(\mu \mathrm{mol} .)\end{array}$} & \multicolumn{2}{|c|}{ Decrease in glucose (mg.) } & \multirow{2}{*}{$\begin{array}{l}\text { Activating effect } \\
\text { (activity of } \\
\text { control = 100) }\end{array}$} \\
\hline & Brain extract & $\begin{array}{l}\text { Brain extract } \\
\text { + haemolysate }\end{array}$ & \\
\hline $\begin{array}{l}10 \\
40\end{array}$ & $\begin{array}{l}0 \cdot 280 \\
0 \cdot 235\end{array}$ & $\begin{array}{l}0.505 \\
0.485\end{array}$ & $\begin{array}{l}180 \\
206\end{array}$ \\
\hline
\end{tabular}

Table 15. Formation of hexosediphosphate by brain extract in presence of haemolysate

(Brain extract, 0.5 ml.; glucose, 11.1 $\mu \mathrm{mol}$.; ATP, $20 \mu \mathrm{mol} . / 6 \mathrm{ml}$. Duration of experiment, $20 \mathrm{~min}$.)

\begin{tabular}{|c|c|c|c|}
\hline $\begin{array}{l}\text { Exp. } \\
\text { no. }\end{array}$ & Addition & $\begin{array}{l}\Delta \text { Glucose } \\
(\mu \mathrm{mol} .)\end{array}$ & $\begin{array}{l}\Delta \mathrm{HDP} \\
(\mu \mathrm{mol} .)\end{array}$ \\
\hline 1 & $\begin{array}{l}\text { Nil } \\
\text { Iodoacetate (1 mM) } \\
\text { Haemolysate } \\
\text { Haemolysate + iodoacetate (1 mM) }\end{array}$ & $\begin{array}{l}-5 \cdot 5 \\
-5 \cdot 5 \\
-9 \cdot 6 \\
-8 \cdot 8\end{array}$ & $\begin{array}{l}5 \cdot 1 \\
3 \cdot 9 \\
5 \cdot 1 \\
8 \cdot 5\end{array}$ \\
\hline 2 & $\begin{array}{l}\text { Iodoacetate }(2 \mathrm{mM}) \\
\text { Haemolysate + iodoacetate ( } 2 \mathrm{mM})\end{array}$ & $\begin{array}{l}-4 \cdot 5 \\
-8 \cdot 5\end{array}$ & $\begin{array}{l}2 \cdot 5 \\
6 \cdot 2\end{array}$ \\
\hline 3 & $\begin{array}{l}\text { Nil } \\
\text { Haemolysate, dialysed }\end{array}$ & $\begin{array}{l}-3 \cdot 6 \\
-5 \cdot 6\end{array}$ & $\begin{array}{l}2 \cdot 6 \\
4 \cdot 1\end{array}$ \\
\hline
\end{tabular}

Table 16. Phosphate balance of phosphorylation of glucose by rat-brain extracts in presence of haemolysate

(Brain extract, 0.9 ml.; glucose, $16.67 \mu \mathrm{mol}$.; ATP, $40 \mu \mathrm{mol}$; haemolysate, $3 \mathrm{ml} . / 10 \mathrm{ml}$. Duration of experiment, $20 \mathrm{~min}$.)

\begin{tabular}{|c|c|c|c|c|c|c|c|c|c|}
\hline $\begin{array}{l}\text { Exp. } \\
\text { no. }\end{array}$ & $\underset{(\mu \text { mol. })}{\Delta \text { Glucose }}$ & $\begin{array}{c}\text { Activating } \\
\text { effect } \\
\text { (control } \\
=100)\end{array}$ & $\underset{\substack{(\mu \mathrm{mol} .) \\
\text { Inorganic }}}{\Delta}$ & $\underset{(\mu \operatorname{mol} .)}{\left.\Delta P_{7 \min }\right)}$ & $\begin{array}{c}\text { P utilized } \\
(\mu \mathrm{mol} .)\end{array}$ & $\begin{array}{l}\Delta \text { ATP } \\
(\mu \text { mol. })\end{array}$ & $\begin{array}{c}\text { ATP } \\
\text { utilized } \\
(\mu \mathrm{mol} .)\end{array}$ & $\begin{array}{l}\Delta \text { ADP } \\
(\mu \mathrm{mol} .)\end{array}$ & $\frac{P \text { utilized }}{\Delta \text { Glucose }}$ \\
\hline $\begin{array}{l}1 \\
2 \\
3^{*}\end{array}$ & $\begin{array}{l}-14 \cdot 2 \\
-16 \cdot 2 \\
-11 \cdot 7\end{array}$ & $\begin{array}{l}201 \\
140 \\
162\end{array}$ & $\begin{array}{l}3.9 \\
3 \cdot 0 \\
1 \cdot 3\end{array}$ & $\begin{array}{l}-27 \cdot 3 \\
-33 \cdot 7 \\
-24 \cdot 0\end{array}$ & $\begin{array}{l}23 \cdot 4 \\
30 \cdot 7 \\
22.7\end{array}$ & $\begin{array}{l}-14 \cdot 8 \\
-16 \cdot 2 \\
-12 \cdot 0\end{array}$ & $\begin{array}{l}12 \cdot 8 \\
14 \cdot 7 \\
11 \cdot 3\end{array}$ & $\begin{array}{c}2 \cdot 2 \\
-1 \cdot 2 \\
0\end{array}$ & $\begin{array}{l}1.65 \\
1.90 \\
1.94\end{array}$ \\
\hline
\end{tabular}


limitation imposed by myokinase activity, but to an inhibition by ADP. Were it otherwise one would have to assume a dual effect of the haemolysate, one on the hexokinase reaction and another on the myokinase reaction. It would be unlikely, in this case, that the difference in the relative rates of ATP and ADP utilization would remain constant.

This discussion, of course, is based on the assumption that animal hexokinases, like yeast hexokinase, are unable to utilize ADP directly as phosphate donor. Preliminary experiments with preparations of muscle hexokinase have indeed shown that the ability to react with ADP decreases with increasing purification.

Hexosediphosphate formation and phosphate balance. Tables 15 and 16 show that, as judged by the ratios of hexosediphosphate formation/glucose disappearance and $P$ utilization/glucose disappearance, the reaction mechanism is not noticeably changed in the presence of dialysed or iodoacetate-poisoned haemolysate. Neither is there any significant increase in the formation of inorganic phosphate or ADP. These experiments, therefore, throw no further light on the mechanism of the activation effect.

\section{DISCUSSION}

The experiments described in this paper have established the existence of an activator of hexokinase in erythrocytes. The activator is a protein which is not identical with a number of enzymes known to be involved, directly or indirectly, in the process of glycolysis. No indication was found for the possibility that the activation was secondary to some changes in the reaction mechanism, such as an increase in the resynthesis or stability of ATP, or the removal of an inhibitory reaction product.

The activation effect appears to be due to a specific reaction, since the factor cannot be replaced by a number of unspecific proteins and since it only affects hexokinase. It is not our impression that the function of the factor is merely protective, since there was no appreciable falling off of hexokinase activity during experimental runs under the conditions used.

An identical or very similar principle has been found in muscle extracts (Weil-Malherbe \& Bone, $1951 b)$, and a more detailed discussion will be deferred until these experiments have been described.

\section{SUMMARY}

1. Red blood corpuscles of man and other species were found to contain a factor which increased hexokinase activity of rat-brain extracts and, to a smaller extent, the activity of rat-muscle hexokinase and of purified yeast hexokinase. In the majority of experiments the activity of brain hexokinase was about doubled in presence of the factor, but the highest effect observed was a sixfold increase of activity.

2. The effect on the phosphorylation of fructose by brain extracts was similar to that with glucose. The activity of phosphohexokinase, on the other hand, was unaffected.

3. The activator did not diffuse on dialysis and could not be separated from protein. It is not present in the stroma of the erythrocyte and is not identical with haemoglobin. It is comparatively heat stable, but loses its activity gradually when exposed to temperatures of $80-100^{\circ}$. Even after heating, the activity was associated with coagulated protein.

4. The activating effect cannot be adequately explained by the presence of hexokinase, phosphohexokinase, triosephosphate dehydrogenase or myokinase in the erythrocyte lysates. A study of the end products of the hexokinase reaction did not reveal any change of reaction mechanisms.

\section{REFERENCES}

Bernstein, S. S., Jones, R. L., Erickson, B. N., Williams, H. H., Avrin, I. \& Macy, I. G. (1937). J. biol. Chem. 122, 507.

Drabkin, D. L. (1949). Arch. Biochem. 21, 224.

Nelson, N. (1944). J. biol. Chem. 153, 375.

Roe, J. H. (1934). J. biol. Chem. 107, 15.

Taylor, J. F. \& Hastings, A. B. (1939). J. biol. Chem. 131, 649.
Weil-Malherbe, H. (1948). Biochem. J. 43, lxi.

Weil-Malherbe, H. (1949). lst Int. Congr. Biochem. Abstr. p. 398.

Weil-Malherbe, H. (1950). Nature, Lond., 165, 155.

Weil-Malherbe, H. \& Bone, A. D. (1951 a). Biochem. J. 49, 339.

Weil-Malherbe, H. \& Bone, A. D. (1951 b). Biochem. J. 49, 355. 